\title{
Karakteristik Iket Sunda di Bandung dan Sumedang Periode Tahun 1968-2006
}

\author{
Suciati \\ Program Studi Tata Busana \\ Universitas Pendidikan Indonesia
}

\begin{abstract}
The study discusses the design of Iket Sunda as it is related to the life of Sundanese people and their associated culture. Iket is a type of traditional head-attire of Sunda, in which through its use we may grasp the function and status of those who wears it. Unfortunately, the use of traditional iket Sunda is no longer common and no one seems to wear it in daily basis. Yet, iket Sunda carries more than just fashion, as it also represent distinct identity amongst diverse ethnic cultures of Indonesia. This study exposes the knowledge behind iket Sunda, from the embedded aesthetic values, the associated behavior of the people who wears it, and its inter-related historical background. To address the purpose, this study applied qualitative approach based on cultural transformation theory, in order to understand the undergone changes that may relate to the design of iket-Sunda. Results indicate that iket Sunda is not completely washed out of use in today's living, as a small group of Sundanese societies in Bandung and Sumedang still wear it on a daily basis. However, some Sundanese people only wear it as part of complete traditional attire in certain events, including dance costumes and other performance activities, therefore most are not aware of the various styles of iket-Sunda. Study found that through times, iket Sunda has undergone changes on the shape, use of clothes, size, decorations, colors, and way of wearing. As rare as it may be, iket Sunda represents the true identity of Sundanese people and their associated culture.
\end{abstract}

Keywords: Iket Sunda; Sundanese culture; traditional costume.

\section{$1 \quad$ Pendahuluan}

Nilai keindahan (aesthetic values) dalam berbusana tradisi bagi masyarakat Sunda khususnya merupakan bagian dari tatakrama. Busana tradisional Sunda memiliki aturan tersendiri dalam pemakaiannya. Penataan pemakaian busana dilakukan demikian dengan maksud untuk mengangkat kualitas kehidupan bermasyarakat. Hal ini didasarkan karena masyarakat Sunda memiliki pandangan atau norma dan etika tersendiri dalam berbusana dan selalu diajarkan setiap keluarga kepada anak-anaknya. Seperti peribahasa Sunda [1] D.K Ardiwinata bahwa: "jawadah tutung biritna, sacara-carana (adat istiadat tidaklah sama di mana-mana, setiap bangsa atau suku bangsa memiliki adat yang berbeda)". D.K Ardiwinata juga menyebutkan bahwa:"saur sepuh: 
barudak ari jadi jelema kudu hadé tata, hadé basa, ambéh loba nu resep, ulah sok goréng gogog, goréng tagog, ka nu kitu mah sok loba nu ijid, temahna loba musuhna (kata orang tua: anak-anak, kalau jadi manusia harus baik dan menarik dalam berpenampilan dan berbahasa, supaya banyak yang simpati, jangan sekali-kali berbicara dan bertingkah laku yang tidak sopan karena itu akan menyebabkan banyak orang benci, sehingga kita banyak musuhnya)”.

Busana tradisional Indonesia umumnya berasal dari bentuk dasar busana bungkus, bentuk kutang, bentuk kaftan dan bentuk celana. Kaftan menurut Arifa [2] merupakan busana bagian atas seperti blouse yang memiliki belahan pada bagian muka, sedangkan menurut Oxford Advanced Learner's Dictionary [3] kaftan also caf-tan is a long loose piece of clothing, usually with a belt at the waist, worn by men in Arab countries, and a woman's long loose dress with long wide sleeves. Salah satu bentuk busana bungkus yang merupakan milineris adalah tutup kepala. Milineris merupakan benda-benda yang melengkapi busana dan berguna langsung bagi pemakainya, seperti alas kaki, tas, topi, ikat pinggang, kaus kaki, sarung tangan, selendang atau kain bahu (scarf, syawl dan stola), sedangkan aksesoris adalah benda-benda yang menambah keindahan bagi pemakainya di antaranya cincin dan gelang, giwang dan anting, serta kalung. Kedua jenis pelengkap busana ini dipakai wanita dan pria dengan berbagai bentuk, warna, model dan tentunya berbagai kesempatan berbusana.

Tutup kepala (head cover) merupakan bagian dari kelengkapan berbusana baik busana tradisional maupun busana moderen. Secara umum busana tradisional Indonesia untuk pria menggunakan tutup kepala sebagai salah satu pelengkap dalam berbusana, baik berbentuk topi maupun ikat kepala. Tutup kepala yang berbentuk ikat kepala, merupakan salah satu jenis tutup kepala yang terbuat dari kain. Tutup kepala di Indonesia memiliki kekhasan pada setiap daerah baik dari segi bentuk maupun bahan pembuatannya. Di Jawa Barat khususnya masyarakat Sunda, tutup kepala yang dibuat dari kain dikenal dengan sebutan iket atau totopong atau udeng, semuanya adalah pelindung kepala yang berfungsi sebagai kelengkapan berbusana. Di samping itu ada pula dudukuy yaitu tutup kepala yang terbuat dari tumbuh-tumbuhan seperti bambu, kayu dan daun yang hanya berfungsi sebagai pelindung kepala dari panas dan hujan. Iket lebih dulu dipakai masyarakat Sunda sebelum ditemukannya dudukuy. Dudukuy memiliki makna simbolik yang lebih rendah di bandingkan iket. Pada zaman dahulu iket juga mencerminkan kelas dalam masyarakat, hingga tampak jelas perbedaan kedudukan seseorang (pria) dalam kehidupan sehari-hari. Di samping itu iket Sunda juga sebagai bagian dari kelengkapan berbusana yang digunakan juga untuk memenuhi kebutuhan budaya yang dikaitkan dengan nilai budaya, adat istiadat serta pandangan hidup masyarakat. 
Iket kini sudah jarang dikenakan dan kalaupun dipakai bentuknya sudah berubah dan bersifat lebih praktis. Di tengah kecenderungan berbusana barat dewasa ini, masih ada orang Sunda yang memakai busana daerah baik sebagai busana sehari-hari maupun untuk waktu-waktu tertentu. Akan tetapi dapat dirasakan bahwa bagi sebagian besar masyarakat Sunda dewasa ini, nilai berbusana daerah berubah dibandingkan dengan nilai berbusana daerah pada masa lalu. Tutup kepala tradisional khususnya iket Sunda dalam perkembangannya tidak dapat diabaikan dengan kehidupan masyarakat serta segala aspek yang mempengaruhinya.

\section{Sejarah Iket Sunda}

Iket merupakan jenis tutup kepala tradisional yang terbuat dari kain dan dipakai dengan teknik tertentu seperti dilipat, dilipit, dan disimpulkan sebagai pengikat akhir. Iket dipakai oleh pria dari berbagai kalangan baik ulama, penghulu, pegawai pemerintahan, masyarakat golongan bawah, mulai dari anak usia sekolah sampai orang tua, dan juga bangsawan.

Iket disebut juga totopong yang terbuat dari kain atau boéh atau mori. Totopong merupakan bentuk iket yang lebih rapi. Dulu boéh diartikan kain. Ada yang disebut boéh alus (kain halus), boéh siang (kain merah) dan boéh larang atau kain yang mengandung kekuatan. Sekarang kata boéh berarti kain putih, yang menurut kamus Umum Basa Sunda [4] boéh nyaeta lawon bodas tina kapas (boéh adalah kain putih dari kapas). Kain yang lebih halus dari boéh disebut kaci. Kata boéh sekarang ini mengalami penyempitan makna menjadi kain putih yang dipakai untuk membungkus mayit atau mayat atau yang dikenal dengan kain kafan. Kain untuk iket Sunda selain menggunakan batik, pada jaman dahulu sebelum mengenal batik menggunakan kain polos yang disebut hideungan (kain berwarna hitam) yang dikenal dengan nama Sandelin. Kain ini dapat pula dipakai untuk celana panjang, kamprét, dan calana pangsi.

Selain iket, masyarakat Sunda juga mengenal tutup kepala yang lain yang terbuat dari kain dengan teknik tertentu yaitu teregos dan igal. Teregos merupakan tutup kepala yang terbuat dari kain seperti tutup kepala yang dipakai pada busana orang Arab dan orang India, sedangkan igal merupakan ikat kepala atau alat untuk memperkuat kedudukan sorban. Igal dibuat dari benang sutera atau dari jenis benang lain.

Tutup kepala atau pun semua benda yang digunakan di kepala (headgear) merupakan perlengkapan busana, karena itu perkembangannya pun sejalan dengan perkembangan bidang busana. Seiring dengan fungsi busana, pada mulanya tutup kepala dikenakan untuk melindungi kepala dari sengatan matahari dan guyuran air hujan. Kebiasaan memakai tutup kepala telah 
berlangsung lama. Pada masa prasejarah orang memanfaatkan tumbuhan berdaun lebar yang tumbuh di sekitarnya untuk menutup kepala. Saat manusia menggunakan kulit kayu sebagai bahan pembuatan busana, tutup kepala dibuat pula dari bahan yang sama dengan cara disambung-sambungkan.

Pengetahuan manusia di bidang teknologi menghasilkan kain yang dapat digunakan sebagai pelengkap berbusana dengan cara diikatkan pada kepala. Penggunaan tutup kepala yang dikaitkan dengan nilai adat istiadat atau pandangan hidup biasanya memiliki arti dan perlambang. Arti dan perlambang dalam tata busana ada sehubungan dengan hadirnya lembaga pemerintah maupun pranata sosial bersamaan dengan munculnya kerajaan pada masa Hindu-Budha, Islam, maupun pemerintahan Kolonial. Pada masa itu lahir bentuk-bentuk tutup kepala yang dapat membedakan kedudukan sosial seseorang. Selain bentuknya, perbedaan-perbedaan tampak dari bahan serta ragam hiasan yang disertakannya.

Tutup kepala diperkirakan muncul pada saat manusia membutuhkan sesuatu untuk melindungi tubuhnya terutama kepala. Untuk mendapatkan pelindung kepala, manusia memanfaatkan bahan-bahan alam yang ada di sekitarnya, seperti tumbuh-tumbuhan yang berdaun lebar yaitu daun keladi dan daun pisang. Tanpa melalui proses pembuatan karena sifatnya yang mudah rusak, daun-daun tersebut dapat langsung dimanfaatkan sebagai pelindung.

Perkembangan berikutnya, pelindung kepala dibuat dari bahan-bahan alam antara lain dari kulit bambu. Beberapa lembar potongan kulit bambu disambungkan dan bentuknya bundar sehingga dapat menutupi bagian kepala. Benda semacam ini disebut dudukuy. Kepandaian masyarakat dalam menganyam telah memperkaya bentuk dudukuy di Jawa Barat dengan munculnya dudukuy cetok. Kini pembuatannya tidak terbatas pada dudukuy saja tetapi berkembang menjadi bentuk-bentuk lainnya antara lain topi bergaya Eropa.

Pemakaian tutup kepala juga dihubungkan dengan etika menghormati atasan atau tokoh yang diagungkan. Hal ini muncul setelah manusia mengenal simbol atau perlambang sebagai perwujudan dari suatu pandangan hidup. Menurut pandangan masyarakat pemimpin atau kepala suku adalah penguasa agung yang mampu mengurus kehidupan sehingga manusia dapat hidup aman, tenteram, dan bahagia. Oleh karena itu pemimpin perlu dijunjung tinggi dan dihormati. Pemakaian iket pada kepala diduga sehubungan dengan adanya kebiasaan kaum pria saat itu untuk memanjangkan rambutnya. Dalam kesehariannya rambut mereka disanggulkan di atas ubun-ubun kemudian kepalanya diikat sedemikian rupa sehingga bila sanggul dilepas rambutnya tidak tergerai. 
Status sosial masyarakat Sunda didasarkan pada tiga tingkatan yaitu golongan cacah atau somah (orang kebanyakan), santana (golongan menengah) dan ménak (golongan bangsawan) yang dapat dibedakan dengan pemakaian busananya baik busana utama, busana pelengkap maupun busana penghiasnya. Hal ini terjadi karena adanya pengaruh budaya Jawa memasuki wilayah Sunda, dalam sejarah penggunaan bahasa Sunda di Tatar Sunda disebutkan kondisi ini terjadi sebagai pengaruh bahasa Jawa dalam kehidupan berbahasa masyarakat Sunda. Pengaruh bahasa Jawa sangat jelas dalam kehidupan berbahasa masyarakat Sunda tampak sejak akhir abad ke-17 hingga pertengahan abad ke19 sebagai dampak pengaruh budaya Mataram. Pada masa itu fungsi bahasa Sunda sebagai bahasa tulisan di kalangan kaum elit terdesak oleh bahasa Jawa, karena bahasa Jawa dijadikan bahasa resmi di lingkungan pemerintahan. Selain itu tingkatan bahasa atau undak usuk basa dan kosa kata Jawa masuk pula ke dalam bahasa Sunda yang mengikuti pola bahasa Jawa yang disebut anggah ungguh basa. Dengan penggunaan tingkatan bahasa terjadilah stratifikasi sosial secara nyata pada masyarakat Sunda.

\subsection{Makna Iket Sunda}

Pada mulanya kata iket merupakan kata umum yang artinya ikat atau ikatan. Akan tetapi karena sesuatu yang diikatnya itu kepala (pria) dan berlangsung saat dangdan atau dangdos atau berdandan akhirnya kata iket itu menjadi kata khusus atau istilah yang mengandung pengertian ikat kepala. Menurut Hidayat Suryalaga [5] kata iket berasal dari dua suku kata yaitu $i$-ket, suku kata akhir ket dalam bahasa Sunda menunjukkan kata yang mengandung makna pageuh (kuat) seperti halnya ti-pe-pe-re-ket (menahan sekuat tenaga), ket-an (beras ketan) yang memiliki sifat cepel (lengket atau menempel kuat).

Iket dengan berbagai bentuk dan wujudnya dipakai dengan suatu pertimbangan akan keserasian, kesopanan serta kepercayaan masyarakat setempat, karena unsur-unsur tadi terikat oleh adat yang kuat dan berlaku sejak dahulu. Iket Sunda khususnya di wilayah Parahyangan muncul dan ada merupakan salah satu usaha pemikiran yang berkenaan dengan norma sehingga selain memikirkan bahan baku yang tepat, proses pembuatan kain maupun menciptakan bentuk wujud iket tidak terlepas dari pemikiran tentang kegunaannya.

Iket dipandang dan dianggap tepat sebagai benda yang dapat melindungi kepala saat melakukan aktifitas dan sekaligus menjadi atribut sosial. Bentuknya yang beragam diciptakan sebagai simbol yang berkaitan dengan keagamaan, upacara adat, dan status sosial tokoh-tokoh masyarakat yang dianggap mempunyai peranan dalam suatu kelembagaan. 
Iket berpadanan kata dengan totopong dan udeng (bahasa Sunda halus). Ditotopong berarti mengenakan tutup kepala menurut aturan tertentu. Bentuk totopong seperti dijelaskan Atik Soepandi [6] bahwa "bentuk totopong itu ada yang disebut Bendo, Porténg, Lohén, Barangbang Semplak atau Mantokan, Kuda Ngencar dan Paros Nangka atau Kebo Modol".

Iket sebagai bagian dari kelengkapan anggoan pameget (busana pria) memiliki nilai estetik tinggi. Iket sebagai tutup kepala memiliki nilai yang lebih berharga dibandingkan dengan tutup kepala yang lain, karena dalam proses pembentukannya memerlukan kejelian, keterampilan, ketekunan, kesabaran dan rasa estetika yang tinggi dari pemakainya. Hal ini akan membuktikan bahwa iket dapat mencerminkan status simbol pemakainya.

Selain itu iket juga memiliki makna secara ilmu pengetahuan dan kepercayaan, seperti dituturkan Nandang Sunaryo [6] bahwa iket sangat erat kaitannya dengan unsur tauhid dan budaya. Iket memiliki makna mengikat seperti ikatan yang terbentuk dari tali. Iket juga berarti totopong yang berasal dari kata tepung (bertemu) yang mengalami pengulangan dan perubahan kata dasar te menjadi toto. Tepung artinya bertemu, bertemu dalam hal ini maksudnya simbol dari bertemunya ujung kain karena dibentuk simpul sebagai lambang silaturahmi. Iket mengandung makna mengikat kepala. Obyek yang diikat adalah kepala (pria). Kepala memiliki makna sebagai pemimpin tubuh dengan isinya yaitu otak. Otak merupakan tempat pikiran dan organ manusia sebagai ciri manusia makhluk mulia ciptaan Tuhan. Dengan otak ini manusia memiliki cipta, karsa, rasa sehingga mampu berpikir. Dengan memakai iket, kepala sebagai organ penting dapat dilindungi.

Iket dibentuk dari kain berbentuk bujur sangkar yang memiliki empat sudut. Keempat sudut itu memiliki makna sebagai sudut kereteg haté (kereteg $=$ perasaan atau suara yang timbul dengan sendirinya, haté $=$ hati. kereteg haté diartikan sebagai niat), ucapan (lisan), tingkah (sikap), dan raga (badan) yang kemudian kain itu dilipat dua membentuk segitiga sama kaki dengan tiga sudut. Ketiga sudut tersebut seperti diutarakan Adil Fadilah Kusumah [7] mencerminkan tiga azas tritunggal kesetaraan dalam hidup kemasyarakatan yakni tritangtu yang terdiri dari resi pemimpin agama, rama (pemimpin rakyat) dan perebu (pemimpin wilayah). Diharapkan azas ini dijalankan dengan keharmonisan antara tekad, ucapan, tingkah laku yang terangkum dalam raga manusia. Iket juga memiliki makna ngawengku (mengikat) segala urusan yang berhubungan dengan keduniawian seperti yang disampaikan Sukatma [8] bahwa iket digunakan oleh para Saéhu. Saéhu adalah seorang pemimpin rakyat yang saé jadi hulu, saé hubungannana, tiasa ngiket kana sagala persoalan kamasyarakatan jeung kahirupan (bagus untuk dijadikan ketua atau pemimpin, bagus hubungan sosialnya, mampu mempersatukan dan menyelesaikan 
persoalan kemasyarakatan dan persoalan kehidupan). Pada masyarakat Sunda khususnya dalam paribasa (peribahasa) dikenal ungkapan caringcing pageuh kancing saringset pageuh iket.

\section{$2.2 \quad$ Fungsi Iket Sunda}

Iket dipakai masyarakat Sunda khususnya pria sebagai kelengkapan berbusana dengan dasar pemikiran mencapai kemuliaan seperti disampaikan Ecep Hidayat [9] bahwa masyarakat Sunda atas kesadaran diri dan sudah menjadi suatu norma dalam berbusana memakai tutup kepala berupa iket dipakai untuk berbagai kesempatan sebagai cara mencapai kajatnikaan (kemuliaan). Dalam kesempatan tertentu seperti bepergian, nyémah (bertamu) atau menghadiri upacara adat pria Sunda memakai iket.

Dalam bersikap dan berkomunikasi masyarakat Sunda tidak menyampaikan maksudnya secara langsung sehingga dalam dunia kebendaanpun prinsip ini menjadi adat yang tampak jelas. Masyarakat Sunda pada umumnya dalam bertindak selalu berpegang pada prinsip silib (mengumpamakan), sindir (mengkritik secara tidak langsung), jeung siloka (dan melambangkan) sehingga pada umumnya benda-benda yang dibuatpun memiliki makna simbolik.

Iket juga menentukan status sosial seseorang. Misalnya pada upacara perkawinan, tutup kepala yang digunakan pengantin pria ialah iket atau totopong sedangkan pada golongan menengah ke atas tutup kepala dibentuk sebagai bendo. Biasanya corak batik yang dipakai adalah batik uwit. Dalam perkawinan keturunan bangsawan Sumedang tutup kepala yang dipakai biasanya meniru tutup kepala ksatria dalam pewayangan yang disebut makuta (mahkota).

Dari keterangan di atas dapat dijelaskan bahwa iket memiliki fungsi sebagai berikut:

a. Fungsi praktis

Pada masyarakat biasa iket selain berfungsi untuk menutupi rambut, melindungi kepala, juga berfungsi sebagai senjata untuk membela diri bila tiba-tiba terjadi penyerangan. Selain itu berfungsi sebagai alat untuk menyimpan dan membawa barang.

b. Fungsi estetis

Selain dapat melindungi bagian kepala, iket dapat memperindah penampilan pria dan menjadi unsur pelengkap berbusana yang serasi pada pria.

c. Fungsi simbolis

Nilai simbolis pada iket misalnya ada beberapa jenis bentuk iket yang hanya dipergunakan untuk orang tertentu atau kesempatan tertentu. Seperti iket 
dengan ragam hias tritik untuk anak yang dikhitan, iket dengan ragam hias huruf Arab dipakai oleh para santri dan jenis iket lain yang dipakai berdasarkan status atau kepentingan tertentu pemakainya.

Pada beberapa peninggalan tertulis menyiratkan bahwa iket tidak hanya digunakan sebagai penutup kepala tetapi juga berfungsi sebagai simbol kebesaran. Dengan adanya pelapisan atau kelas-kelas dalam masyarakat, iket berperan sebagai pembeda antara masyarakat kelas tinggi yaitu kaum bangsawan (para pejabat pemerintah), masyarakat kelas menengah atau priyayi (pegawai negeri, masyarakat berekonomi tinggi), golongan ini memakai iket dengan sebutan udeng, serta kelas bawah (cacah dan somah) yaitu pedagang, buruh dan petani memakai iket yang disebut totopong.

Fungsi iket pada masyarakat Sunda tergantung pada tofografi Sunda yang terdiri dari tiga jenis yaitu perbukitan, dataran tinggi dan dataran rendah. Fungsi iket ini sesuai pekerjaan yang mereka kerjakan. Untuk nelayan yang bekerja di basisir (pesisir pantai) iket berfungsi sebagai pelindung kepala dari angin, panas, dan sebagai alat pameungkeut (pengikat). Untuk masyarakat yang bertani, iket berfungsi sebagai pelindung kepala dari panas sinar matahari dan sebagai wawadahan (tempat menyimpan benda) sedangkan pada masyarakat yang berdagang, iket berfungsi sebagai alat untuk membersihkan keringat, sebagai pelindung kepala seperti topi, dan sebagai alat cacandakan (membawa barang).

Setelah datangnya pengaruh budaya Islam, kain untuk iket memiliki fungsi sebagai sajadah yang menurut Kamus Umum Basa Sunda yaitu pangsujudan, biasa mangrupa samak atawa alketip leutik saurangeun (tempat sujud, biasanya berupa tikar atau permadani untuk satu orang). Sajadah digunakan sebagai alas untuk melakukan sholat lima waktu. Selain itu iket berfungsi pula sebagai penahan rambut pada saat sholat terutama pada saat melakukan sujud agar taar (dahi) tidak terhalangi oleh rambut.

\subsection{Ukuran Kain yang Digunakan untuk Iket Sunda}

Iket atau totopong terbuat dari kain atau boéh atau mori. Ukuran kain yang biasa dipergunakan untuk iket adalah:

a. Saiket atau satotopong atau sekacu, dengan ukuran 90x90 cm atau 100x100 $\mathrm{cm}$ atau $105 \times 105 \mathrm{~cm}$ berbentuk bujur sangkar.

b. Satengah iket atau separon apabila ukuran persegi empat bujur sangkar di atas di bagi dua menjadi segitiga sama kaki. Kain ini banyak digunakan untuk bendo dadakan atau bendo damelan maupun bendo citak. 
Menurut Hidayat Suryalaga [5] untuk iket Sunda kain yang digunakan harus merupakan kain dengan ukuran saiket atau satotopong yang terdiri dari empat sudut karena selain iket Sunda memiliki ciri khas yaitu pada bagian tengah kepala tertutup juga mengandung makna bahwa iket memiliki fungsi sosial dan pemakainya memiliki sikap masagi (manusia yang dapat beradaptasi dengan lingkungan dan keadaan).

Pada perkembangan ragam hias batik khususnya di wilayah Sunda mengalami pengaruh dari daerah lain khususnya Jawa. Nian S. Djumena [10] menyebutkan:

pada umumnya ragam hias batik suatu daerah di pengaruhi dan erat hubungannya dengan faktor-faktor :

1. Letak geografis daerah pembuat batik yang bersangkutan.

2. Sifat dan tata penghidupan daerah yang bersangkutan.

3. Kepercayan dan adat istiadat yang ada di daerah yang bersangkutan.

4. Keadan alam sekitarnya, termasuk flora dan fauna.

5. Adanya kontak atau hubungan antar daerah pembatikan.

Lebih lanjut Atik Soepandi menguraikan bahwa masih dapat ditelusuri namanama tenun batik Sunda, antara lain:
a. Boéh siang
: $\quad$ Boéh $=$ Lawon $=$ kain.
Siang $=$ artinya merah.
Boéh siang berarti kain merah.
b. Gagang senggang : Gagang = tangkai.
Senggang = tanaman perdu yang berduri.
Gagang senggang berarti tangkai tanaman perdu yang berduri.

\section{c. Giringsing \\ d. Hujan riris \\ e. Kalangkang ayakan}
f. Kampuh jayant
g. Kekembangan
h. Kembang muncang : Bunga kemiri.
i. Kembang taraté : Bunga teratai. 
j. Lusian besar : Lusian = benang-benang yang dilukiskan membujur pada tenunan.

Besar = besar.

Lusian besar berarti motif batik yang bergaris membujur yang dilukiskan dengan benang besar.

k. Mangin hiris

: $\quad$ Mangin $=$ angin .

Hiris = tanaman perdu yang buahnya seperti petai hanya berukuran sangat kecil.

Mangin hiris berarti motif batik yang menggambarkan pohon, daun dan buah hiris yang tertiup angin.

1. Parigi nyéngsoh : Parigi $=$ sumber air atau sumur.

Nyéngsoh $=$ miring.

Parigi nyéngsoh berarti sumur atau pagar sumur yang telah miring.

m. Surat awi

: $\quad$ Serat awi = serat bambu dan bambu besar atau gombong. Motif kain yang bergambar serat-serat bambu atau bergambar bambu gombong atau bambu besar.

n. Seumat sahurun : Seumat $=$ peniti atau penusuk.

Sahurun $=$ seikat atau setumpuk.

Seumat sahurun berarti motif batik yang menggambarkan seikat atau setumpuk peniti.

o. Urang-urangan : Urang-urangan = udang-udangan atau huranghurangan atau huhurangan. Motif batik yang menggambarkan udang. Warnanya coklat tua sebagai warna dasar dan coklat muda untuk warna udang. Bisa dibandingkan dengan batik uwit udang sekarang.

Pada saat ini sangat banyak corak batik yang antara lain ada yang dinamakan batik Giringsing, Giringsing Wayang, Kawung Écé, Katuncar Mawur, Kangkung, Kumeli, Keris, Parang Rusak, Parang Sari, Méga mendung, Sidamukti, Léréng Enéng, Soré Isuk, Uwit, Uwit Udang, Pecah Kopi, Jayanti, Bilik, dan Rengganis. Pengrajin batik pada masa lampau disebut pangheuyeuk.

Berdasarkan topografi wilayah Sunda, motif batik yang ada di wilayah Sunda dapat digambarkan sebagai berikut:

Tabel 1 Pemetaan Motif kain batik untuk iket Sunda berdasarkan topografi wilayah Sunda. 


\begin{tabular}{|c|c|c|c|}
\hline \multirow{2}{*}{$\begin{array}{c}\text { Jenis Topografi } \\
\text { Sunda }\end{array}$} & \multicolumn{3}{|c|}{ Motif Batik } \\
\hline & Flora & Fauna & Alam / Barang \\
\hline $\begin{array}{l}\text { Perbukitan } \\
\text { (bagian selatan) }\end{array}$ & $\begin{array}{l}\text { - Taraté(teratai) } \\
\text { - Tumbuhan air } \\
\text { - Ganas (nanas) }\end{array}$ & $\begin{array}{l}\text { - Buhaya (buaya) } \\
\text { - Oray (ular) } \\
\text { - Cakcak (cecak) }\end{array}$ & $\begin{array}{l}\text { - Banji, ceplok, } \\
\text { ganggong, } \\
\text { kawung, parang, } \\
\text { léréng, tiruan } \\
\text { pola anyam }\end{array}$ \\
\hline $\begin{array}{l}\text { Dataran tinggi } \\
\text { (bagian tengah) }\end{array}$ & $\begin{array}{l}\text { - Tanaman perdu } \\
\text { berdaun lebar } \\
\text { - Hanjuang }\end{array}$ & $\begin{array}{l}\text { - Maung (harimau) } \\
\text { - Uncal (kijang) } \\
\text { - Gogog (Anjing) } \\
\text { - Kuda } \\
\text { - Merak (Burung } \\
\text { merak) }\end{array}$ & $\begin{array}{l}\text { - Bentuk-bentuk } \\
\text { geometris (bujur } \\
\text { sangkar, empat } \\
\text { persegi panjang, } \\
\text { lingkaran, belah } \\
\text { ketupat) }\end{array}$ \\
\hline $\begin{array}{l}\text { Dataran rendah } \\
\text { (bagian utara) }\end{array}$ & $\begin{array}{l}\text { - Areuy (Tumbuhan } \\
\text { merambat) } \\
\text { - Sisi laut } \\
\text { - Bako (bakau) }\end{array}$ & $\begin{array}{l}\text { - Hurang (udang) } \\
\text { - Kerang } \\
\text { - Cumi-cumi } \\
\text { - Lauk cai (ikan } \\
\text { laut) }\end{array}$ & $\begin{array}{l}\text { - Méga (awan) } \\
\text { - Seuneu (api) } \\
\text { - Cai (air) } \\
\text { - Batu } \\
\text { - Parahu (perahu) } \\
\text { - Kipas } \\
\text { - Payung }\end{array}$ \\
\hline
\end{tabular}

\subsection{Warna Tradisonal pada Kain Batik Parahyangan}

Warna alami pada kain tenun Sunda diperoleh dengan mencelup kain tenun dengan bahan alam seperti dicelupkan pada leutak (lumpur) untuk memperoleh warna marun (biru kehitaman), pada tarum (nila) untuk memperoleh warna bulao kolot (biru keunguan) dan warna gandaria (ungu kemerah-merahan) serta pada gambir untuk memperoleh warna merah.

Mengenai warna khas Parahyangan seperti ditulis oleh Sulasmi Darmaprawira [11] bahwa warna khas Parahyangan telah banyak diungkapkan dalam bentuk sastra dan puisi atau lagu-lagu Sunda lama seperti Cianjuran dan pada cerita pantun sinyun ada semacam pantun yang disebut sisindiran atau paparikan.

Warna yang dikenal masyarakat Sunda adalah gandaria (ungu), kayas (merah muda), paul (biru ultramarine), héjo paul (biru turquoise). Dikenal pula warna gradasi antara merah dengan biru seperti beureum, kayas kasumba, gandaria, gondola, paul (merah, merah muda, merah muda keunguan, ungu, biru keunguan dan biru ultramarine. Selain itu dikenal pula warna gumading atau gading (krem). Masyarakat Sunda juga mengenal warna sebagai simbolis seperti: 
Tabel 2 Simbol warna bagi masyarakat Sunda.

\begin{tabular}{lll}
\hline \multicolumn{1}{c}{ Warna } & \multicolumn{1}{c}{ Lambang } & \multicolumn{1}{c}{ Penggunaan } \\
\hline Putih & Kesucian & Warna busana pengantin perempuan \\
Merah dan & Keberanian dan & a. Ngaruat rumah baru \\
putih & kesucian & b. Upacara panen pertama kali \\
& & $\begin{array}{l}\text { c. Pemberian nama anak } \\
\text { d. Numbas (kesucian gadis pada saat menikah) }\end{array}$ \\
Kuning & Kejayaan & Upacara berbagai syukuran \\
Hitam dan & Bangun tulak & Pada iket dengan motif batik tritik dan berbagai \\
putih & atau tolak bala & $\begin{array}{l}\text { benda lain agar terhindar dari hal-hal yang tidak } \\
\text { diinginkan }\end{array}$ \\
\hline
\end{tabular}

Menurut Hidayat Suryalaga [5] bahwa warna khas Sunda dipengaruhi oleh keadaan topografi. Pada dasarnya Jawa Barat (Sunda) terdiri dari tiga jenis topografi yang membentang dari barat ke timur, yaitu dataran rendah di bagian utara, dataran tinggi di bagian tengah dan perbukitan di bagian selatan. Dari perbedaan topografi ini menghasilkan warna yang biasa dipakai oleh masyarakat pendukungnya. Uraian warna tradisional Sunda dapat digambarkan sebagai berikut:

a. bagian selatan merupakan perbukitan yang pada umumnya mata pencaharian masyarakatnya adalah nelayan. Warna yang muncul pada daerah ini antara lain mulai dari merah, kuning, oranye, kuning emas dan perak.

b. Bagian tengah merupakan daerah dataran tinggi yang masyarakatnya hidup bertani baik berladang maupun bersawah. Warna pada daerah ini umumnya gradasi dari hijau muda sampai hitam pekat.

c. Bagian dataran rendah merupakan daerah dataran rendah yang masyarakatnya pada umumnya berdagang. Warna pada daerah ini umumnya gradasi dari warna krem sampai coklat tua pekat.

\section{$3 \quad$ Karakteristik Iket Sunda}

Karakteristik bentuk fisik iket Sunda terdiri dari bentuk-bentuk yang diberi nama berdasarkan benda-benda yang ada di lingkungan alam sekitar oleh masyarakat Sunda. Nama-nama itu adalah Barangbang Semplak, Parékos yang terdiri dari jenis Parékos Nangka, Parékos Jéngkol, Tutup Liwet dan Lohén, selain itu Porténg dan Kolé Nyangsang.

Satu sama lain dari bentuk-bentuk yang ada memiliki kesamaan yaitu:

a. Adanya lilitan yang mengikat kepala yang berada di sekeliling dahi sampai dengan belakang kepala. 
b. Adanya bagian berupa selembar kain segitiga yang menutup kepala bagian atas, bagian kain segitiga yang lain dapat menjadi penutup bagian belakang kepala seperti pada model Kolé Nyangsang atau kedua lembar segitiga itu sebagai penutup kepala.

c. Ujung segitiga dapat dimasukkan ke dalam lilitan pengikat seperti pada model Barangbang Semplak, Parékos Jéngkol, Tutup Liwet dan Kolé Nyangsang. Dapat pula setelah dimasukkan ke dalam lilitan pengikat kemudian dikeluarkan lagi seperti pada model Porténg, atau setelah ke luar lilitan pengikat ujungnya di masukkan lagi menyelubungi lilitan pengikat seperti pada model Lohén.

d. Pada umumnya simpul akhir terletak di belakang atau agak ke sebelah samping kepala.

Karakteristik bentuk fisik iket Sunda yang diuraikan di atas dapat digambarkan sebagai berikut:

Tabel 3 Karakteristik Bentuk Fisik Iket Sunda.

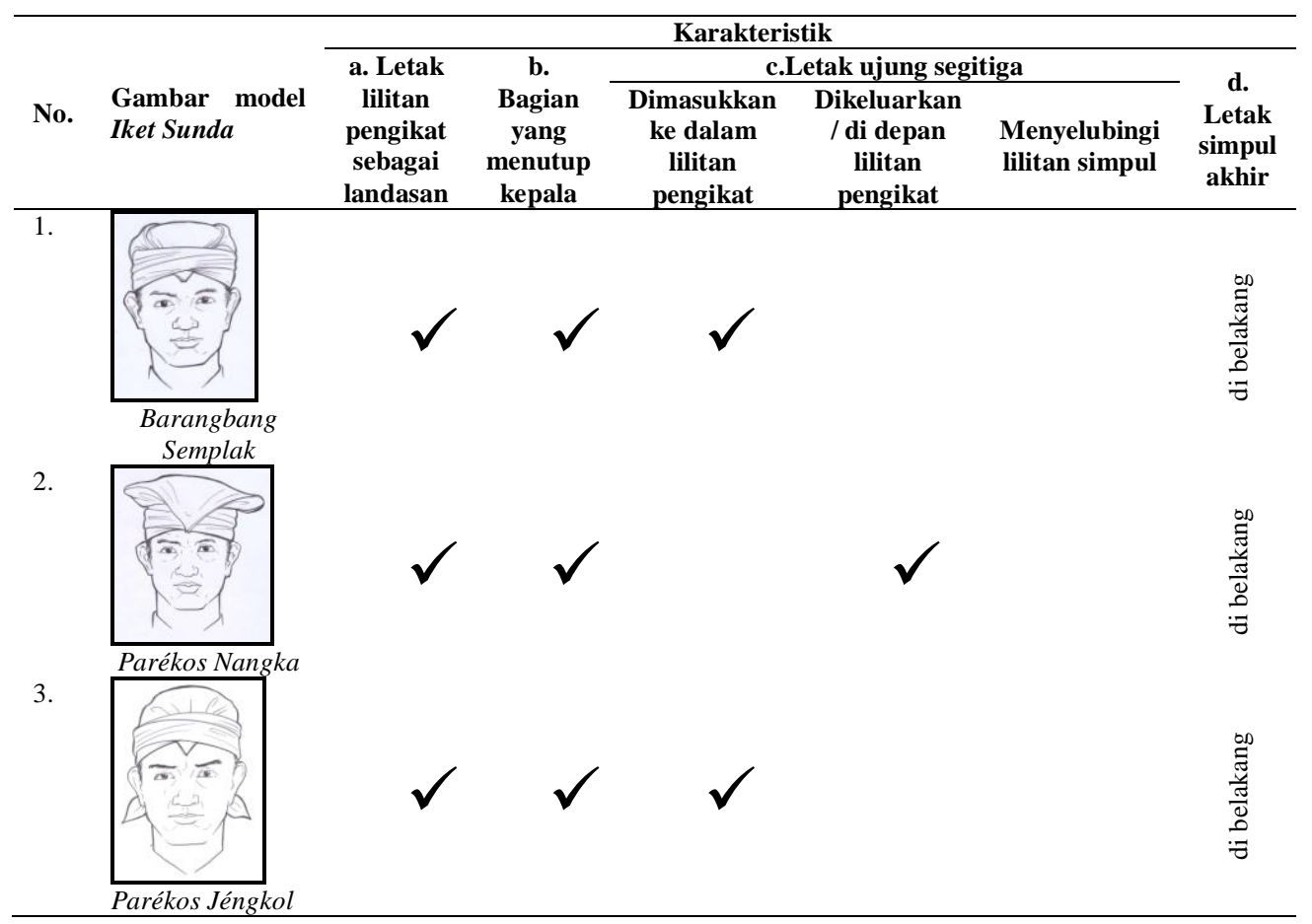




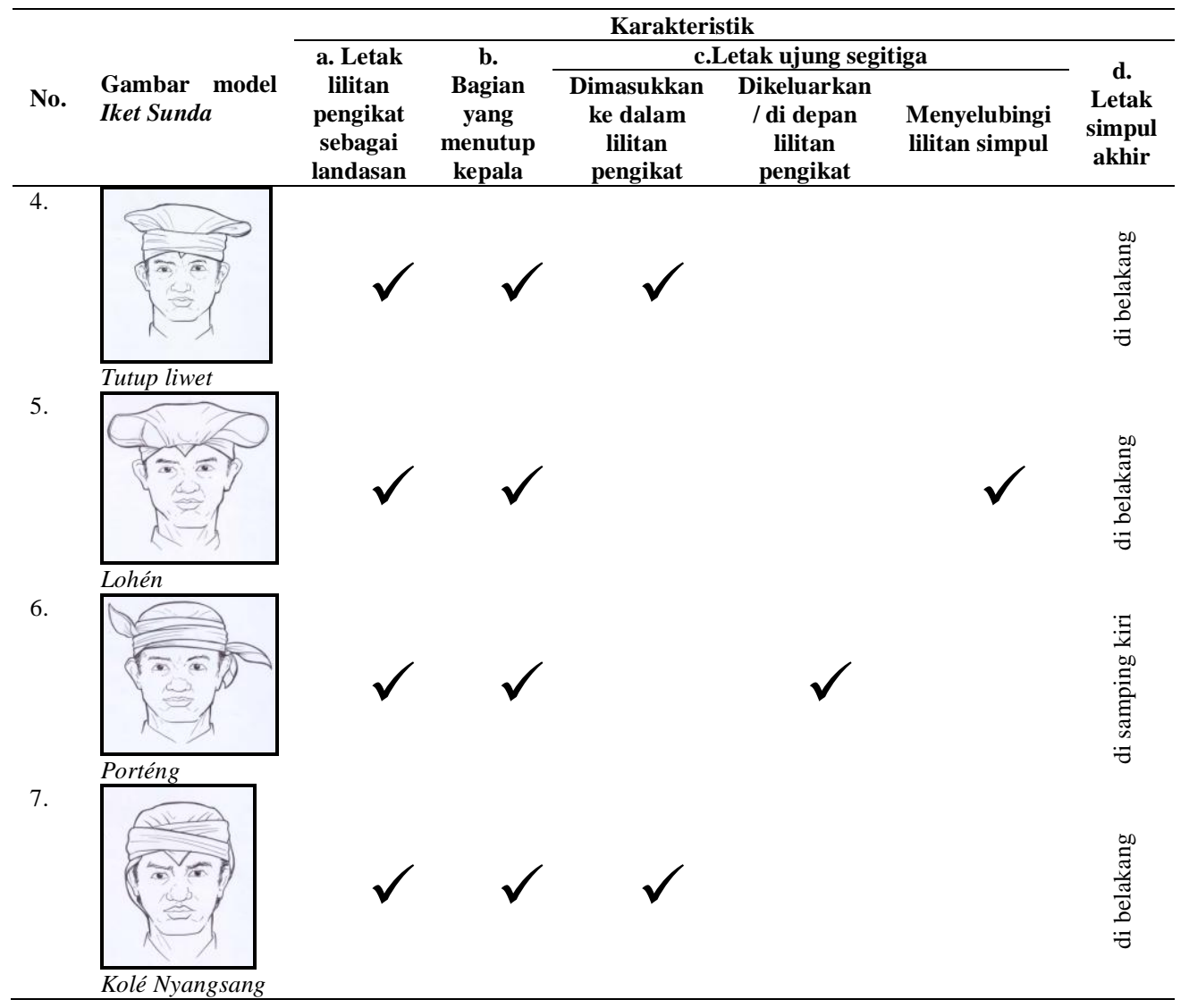

Sekarang ini iket Sunda hampir tidak lagi memiliki karakteristik bentuk fisik seperti yang diuraikan di atas. Kondisi ini sebagai akibat pemakaian kain separon maka bagian atas kepala menjadi terbuka, padahal iket Sunda sebagai penutup dan pelindung kepala memiliki ciri khas yaitu pada bagian atas kepala tertutup. Pemakaian kain separon menyebabkan tidak adanya satu bagian segitiga yang dapat ditarik baik untuk menutupi bagian atas kepala ataupun bagian belakang kepala.

Pemakaian kain separon ini juga menyebabkan bentuk iket Sunda menjadi berbeda dari aslinya. Masyarakat Sunda khususnya di Bandung, pada umumnya tidak lagi mengenal model-model iket Sunda. Model yang masih dikenal adalah Barangbang Semplak dan Parekos. Kedua model ini merupakan model yang paling populer karena selain bentuknya sederhana namanya pun mudah diingat.

Berbagai upacara adat masih dilaksanakan masyarakat Rancakalong Sumedang, Salah satu di antaranya adalah upacara Ngalaksa. Upacara adat Ngalaksa adalah 
upacara adat yang dilakukan masyarakat khususnya petani dari kalangan cacah atau somah dengan maksud mensyukuri hasil panen dengan cara membuat nasi Laksa. Tahapan proses pembuatan nasi Laksa dilakukan dengan upacara adat yang diiringi musik Tarawangsa atau Jentreng dan tarian dari para petani. Tarawangsa atau Jentreng merupakan musik tradisional Sunda dari suara kecapi dan rebab.

Pada pelaksanaan upacara Ngalaksa, para pria tampak menggunakan iket Sunda, khususnya para Saehu dengan berbagai model bergantung kepada kebiasaan setempat dan kebiasaan pemakainya. Namun apabila dilihat lebih teliti model yang digunakan bersumber dari bentuk dasar Parékos yang biasa digunakan oleh para panyawah (petani). Seperti tampak pada gambar para Saéhu (ketua kelompok tani) menggunakan iket Sunda pada upacara Ngalaksa tanggal 6-12 Juli 2006 di Desa Rancakalong Sumedang. Busana padanan yang digunakan oleh para Saéhu pada upacara Ngalaksa tidak lagi menggunakan busana tradisional Sunda melainkan busana pria model barat seperti pemakaian jas, celana panjang, dan kemeja sebagai busana utama.

Pemakaian iket Sunda di kalangan remaja di kota besar sekarang ini merupakan salah satu trend dan kebutuhan dalam berbusana karena adanya kesadaran dari generasi muda untuk menemukan kembali identitas etnis Sunda. Salah satu caranya yaitu dengan pemakaian iket Sunda yang dipakai sebagai hiasan kepala dan dipakai pada berbagai kesempatan berbusana dan tidak terikat oleh ketentuan tradisi baik dalam bentuk maupun corak kain yang digunakan.

Iket Sunda pada masa dahulu merupakan salah satu kelengkapan busana pria yang sangat penting. Penggunaan iket bagi masyarakat Sunda berfungsi sebagai:

a. Penutup rambut.

b. Pelindung kepala.

c. Alat untuk melindungi diri.

d. Alat untuk membawa barang.

e. Alat untuk menyimpan barang.

f. Sebagai sajadah pada saat melaksanakan sholat lima waktu

g. Simbol status sosial pria atau sebagai simbol yang menunjukkan identitas dalam lingkungan pergaulan sehari-hari. Simbol ini ditunjukkan melalui model dan jenis kain yang digunakan untuk iket.

h. Penghormatan terhadap kedudukan seorang pria seperti digunakan apabila menghadap priyayi, pejabat pemerintah setempat dan ulama. 
Fungsi iket Sunda seperti yang disebutkan di atas dipakai sebagai kelengkapan busana sehari-hari baik pada kesempatan formal atau resmi seperti upacara adat maupun acara informal seperti beribadah dan kesempatan berbusana sehari-hari.

Dewasa ini fungsi iket Sunda secara umum sebagai:

a. Salah satu penanda etnis Sunda.

b. Penanda etnis Sunda pada busana adat.

c. Penanda etnis Sunda pada busana tari pertunjukan.

Perubahan yang terjadi pada fungsi iket Sunda dahulu dan sekarang adalah sebagai akibat:

a. Saat ini tidak ada lagi pembagian masyarakat Sunda berdasarkan golongan ménak dan somah/cacah.

b. Berlakunya wajib belajar bagi seluruh rakyat Indonesia termasuk masyarakat Sunda sehingga semua lapisan masyarakat Sunda mendapat pendidikan formal di sekolah-sekolah yang salah satu pahamnya tidak membeda-bedakan strata sosial peserta didik.

c. Adanya keharusan memakai seragam sekolah dengan model busana Eropa sehingga lambat laun busana tradisional ditinggalkan termasuk tidak diberlakukannya lagi tutup kepala tradisional dalam seragam sekolah.

d. Adanya trend memakai busana gaya busana barat yang dipakai sehari-hari oleh masyarakat Sunda sehingga iket Sunda tidak lagi menjadi salah satu kelengkapan berbusana bagi pria. Kondisi ini mendorong seolah-olah iket Sunda hanya dipakai pada saat pria di Sunda mengikuti upacara adat atau dipakai pada busana tari pertunjukan yang menunjukkan tokoh dalam tari tersebut sebagai masyarakat dari golongan somah.

e. Pemakaian iket Sunda dianggap tidak praktis karena memerlukan keterampilan, ketelitian, ketekunan, dan kesabaran dalam memakainya.

f. Bertambahnya jumlah penduduk dan semakin heterogennya masyarakat Sunda saat ini sulit menentukan identitas asli orang Sunda.

Warna yang digunakan untuk iket Sunda pada umumnya adalah warna biru kehitam-hitaman, biru keungu-unguan, ungu kemerah-merahan, merah, krem, dan putih, namun saat ini warna yang digunakan untuk iket Sunda tidak terbatas pada warna yang tradisional saja. Kondisi ini terjadi karena:

a. Pemakaian iket Sunda sebagai pelengkap busana sehari-hari disesuaikan dengan warna busana yang digunakan. Warna busana pria saat ini cenderung mengikuti warna busana yang sesuai dengan gaya busana barat.

b. Pemakaian iket Sunda sebagai pelengkap busana pria pada busana tari pertunjukan pada umumnya disesuaikan antara busana utama dengan tutup 
kepala dan sarung yang dililitkan dipinggang, sebagai contoh tampak pada gambar di bawah ini.

Ragam hias yang digunakan pada kain untuk iket Sunda baik dahulu maupun sekarang pada umumnya menggunakan ragam hias tengahan, blumbungan, byur dan kembangan. Ragam hias pada kain untuk iket Sunda pada umumnya menggunakan ragam hias yang ada pada kain batik seperti banji, kawung, ceplok, garis miring, nitik, renggaan dari bentuk bunga, tumbuh-tumbuhan, binatang, cemukiran, dan isen. Perkembangan hubungan antar daerah juga memungkinkan ragam hias daerah di luar daerah Sunda digunakan pada kain untuk kain iket Sunda.

Namun selain ragam hias yang ada pada kain batik, dewasa ini ditambah dengan hiasan berupa bros, payet, mute, renda dan manik-manik terutama untuk iket Sunda yang dipakai sebagai pelengkap busana pria pada busana tari pertunjukan rakyat.. Hiasan ini dapat pula menunjukkan karakter tokoh yang akan berperan dalam seni pertunjukkan.

Kain untuk iket Sunda dahulu hanya menggunakan kain mori. Meningkatnya teknologi pertekstilan menyebabkan banyaknya pilihan tekstil yang dapat dipakai sebagai kain yang digunakan untuk iket Sunda dengan beragam motif dan warna kain. Kain yang digunakan adalah kain dengan ukuran satotopong atau saiket $(90 \times 90 \mathrm{~cm}$ atau $100 \times 100$ atau $105 \times 105 \mathrm{~cm})$ namun saat ini ukuran kain yang digunakan adalah satengah iket atau separon (kain berukuran satotopong atau saiket dibagi dua berbentuk segitiga sama kaki). Salah satu faktor penyebabnya karena pada umumnya para pedagang batik membagi dua bidang kain iket untuk dijual dan para pemakai iket Sunda merasa lebih nyaman dengan memakai selembar kain berbentuk segitiga yang merupakan setengah bagian dari ukuran satotopong.

Jenis kain yang dapat digunakan untuk iket di antaranya kain yang berasal dari katun, polyester, rayon, satin, sutera, campuran polyester dan katun, serta campuran polyester dan rayon. Motif kain yang digunakan selain motif yang berasal dari bentuk flora, fauna, juga bentuk stilasi dari alat, barang dan bendabenda.

Cara memakai iket Sunda kini selain bersifat tradisional yaitu dibuat langsung juga bersifat praktis dengan adanya iket yang dibuat siap pakai. Kepraktisan pemakaian iket Sunda didorong karena adanya kebutuhan efisiensi waktu. Bentuk iket tidak lagi dibuat langsung saat dipakai tapi dibuat menjadi benda siap pakai. 
Pemakaian iket Sunda mengalami penyempitan makna menjadi pelengkap busana yang sifatnya dipakai untuk kesempatan tertentu dan kepentingan tertentu salah satunya pada kesempatan upacara adat dan kesempatan pentas tari pertunjukan rakyat. Hal ini terjadi karena:

a. Semakin jarangnya pria di Sunda menggunakan iket sebagai pelengkap berbusana.

b. Adanya alat pelindung kepala yang lain yang lebih praktis seperti bermacam-macam model topi dan hélem (helm) yang selain melindungi kepala dari cuaca dan benturan benda keras juga barang-barang tersebut dapat digunakan sebagai pelengkap berbusana yang menunjang penampilan pria dalam gaya busana barat yang dewasa ini lebih banyak dipakai dalam kesempatan berbusana sehari-hari.

c. Adanya bermacam-macam gaya rambut pria baik berpotongan pendek atau panjang dengan berbagai bahan kosmetika perawatan rambut sehingga para pria lebih cenderung menampilkan gaya rambut daripada memakai penutup kepala.

Tabel 4 Pemetaan desain iket Sunda berdasarkan pembabakkan waktu.

\begin{tabular}{|c|c|c|c|}
\hline No. & Waktu & Kondisi & Keberadaan Iket Sunda \\
\hline 1. & 1579 & Kerajaan Sunda runtuh & $\begin{array}{l}\text { Keadaan saat itu } \\
\text { masyarakat Sunda } \\
\text { menggunakan iket atau } \\
\text { tipulung sebagai suatu } \\
\text { kebiasaan }\end{array}$ \\
\hline 2. & $\begin{array}{l}\text { Masa pembentukan } \\
\text { kabupaten-kabupaten } \\
\text { di wilayah } \\
\text { Parahyangan hingga } \\
\text { Masa Awal } \\
\text { kekuasaan Eropa di } \\
\text { wilayah Sunda (1620- } \\
\text { 1808) }\end{array}$ & $\begin{array}{l}\text { a. Wilayah } \\
\text { Sumedanglarang } \\
\text { diserahkan oleh Aria } \\
\text { Suriadiwangsa I } \\
\text { kepada Sultan Agung } \\
\text { dari Mataram } \\
\text { (peristiwa Prayangan) } \\
\text { b. Terjadi pelapisan } \\
\text { sosial pada masyarakat } \\
\text { Sunda: ménak, } \\
\text { santana, cacah atau } \\
\text { somah } \\
\text { c. Pergeseran kehidupan } \\
\text { keagamaan }\end{array}$ & $\begin{array}{l}\text { - Ménak dan santana } \\
\text { menggunakan udeng } \\
\text { - Cacah atau somah } \\
\text { menggunakan totopong } \\
\text { - Iket Sunda sebagai tanda } \\
\text { dalam pergaulan } \\
\text { - Iket Sunda dihubungkan } \\
\text { dengan falsafah } \\
\text { keagamaan khususnya } \\
\text { agama Islam seperti: } \\
\text { 1. Iket dikaitkan dengan } \\
\text { falsafah silaturahmi } \\
\text { 2. Sebagai benda yang } \\
\text { melindungi otak } \\
\text { 3. Sebagai sajadah } \\
\text { 4. Sebagai alat yang } \\
\text { dapat menunjang } \\
\text { salah satu syarat } \\
\text { sahnya sholat }\end{array}$ \\
\hline
\end{tabular}




\begin{tabular}{|c|c|c|c|}
\hline No. & Waktu & Kondisi & Keberadaan Iket Sunda \\
\hline 3. & $\begin{array}{l}\text { Masa awal kolonial } \\
\text { sampai awal } \\
\text { pendudukan Jepang } \\
\text { di wilayah Sunda } \\
(1808-1942)\end{array}$ & $\begin{array}{l}\text { a. Penetrasi bidang sosial } \\
\text { budaya } \\
\text { b. Ikatan tradisional } \\
\text { dicoba diterabas } \\
\text { c. Adanya gaya hidup } \\
\text { kebarat-baratan } \\
\text { d. Kondisi } \\
\text { Kependudukan } \\
\text { menjadi heterogen } \\
\text { e. Berdirinya sekolah- } \\
\text { sekolah sebagai akibat } \\
\text { lahirnya Politik Etis } \\
\text { yang memberlakukan } \\
\text { siswanya memakai iket } \\
\text { tradisional }\end{array}$ & $\begin{array}{l}\text { - Iket Sunda atau } \\
\text { totopong menjadi ciri } \\
\text { khas pelengkap } \\
\text { busana yang } \\
\text { digunakan golongan } \\
\text { somah } \\
\text { - Udeng yang } \\
\text { digunakan golongan } \\
\text { ménak menjadi } \\
\text { beragam bentuk dan } \\
\text { namanya dan } \\
\text { berkembang menjadi } \\
\text { bendo citak dan bendo } \\
\text { damelan } \\
\text { Dikenal ketu udeng } \\
\text { atau bendo untuk tutup } \\
\text { kepala bagi ménak } \\
\text { Muncul berbagai } \\
\text { nama iket Sunda } \\
\text { sesuai versi dan } \\
\text { kebiasaan daerah }\end{array}$ \\
\hline 4. & $\begin{array}{l}\text { Masa pendudukan } \\
\text { Jepang (1942-1945) }\end{array}$ & $\begin{array}{l}\text { a. Diberlakukannya } \\
\text { politik propaganda } \\
\text { Jepang sebagai saudara } \\
\text { tua bangsa Indonesia } \\
\text { b. Jepang menjalankan } \\
\text { politik men-Jepang- } \\
\text { kan Indonesia } \\
\text { c. Kehancuran segala } \\
\text { bidang kehidupan }\end{array}$ & $\begin{array}{l}\text { Iket Sunda sebagai } \\
\text { pelengkap busana } \\
\text { ditinggalkan dan } \\
\text { diganti dengan } \\
\text { dudukuy dan kopéah }\end{array}$ \\
\hline
\end{tabular}




\begin{tabular}{|c|c|c|c|}
\hline No. & Waktu & Kondisi & Keberadaan Iket Sunda \\
\hline 5. & $\begin{array}{l}\text { Masa Republik } \\
\text { Indonesia (1945- } \\
1965)\end{array}$ & 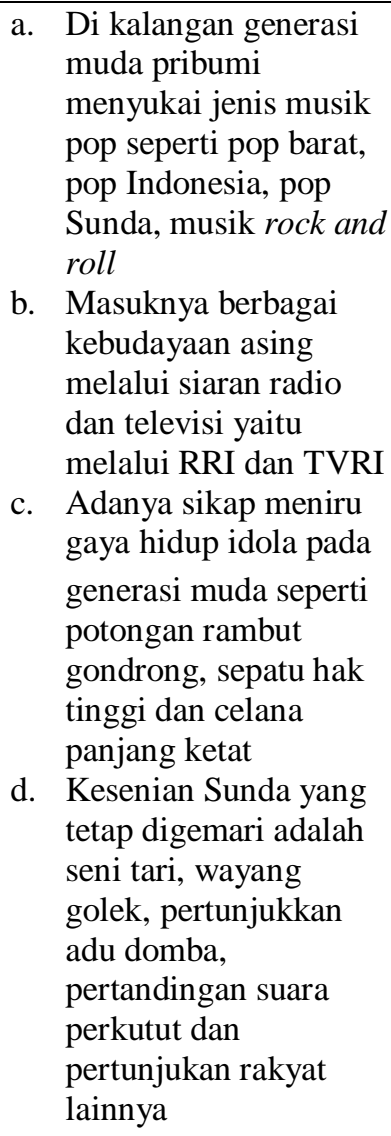 & $\begin{array}{l}\text { - } \text { Busana tradisional } \\
\text { khususnya iket mulai } \\
\text { tergeser } \\
\text { - Busana tradisional } \\
\text { hanya dipakai oleh } \\
\text { para orang tua dan } \\
\text { masyarakat di } \\
\text { pinggiran kota } \\
\text { Busana tradisional } \\
\text { termasuk iket Sunda } \\
\text { dipelihara dan } \\
\text { dilestarikan di } \\
\text { lingkungan seni }\end{array}$ \\
\hline 6. & $\begin{array}{l}\text { Masa Orde Baru } \\
\text { hingga masa } \\
\text { Reformasi (1968- } \\
\text { 2006) }\end{array}$ & $\begin{array}{l}\text { a. Maraknya dunia } \\
\text { hiburan film melalui } \\
\text { gedung-gedung } \\
\text { bioskop } \\
\text { b. Upaya penggalian } \\
\text { budaya asli banyak } \\
\text { dilakukan generasi } \\
\text { muda } \\
\text { c. Berbagai kunjungan } \\
\text { muhibah keluar negeri } \\
\text { maupun misi-misi } \\
\text { budaya dari luar negeri } \\
\text { d. Para pelaku seni dan } \\
\text { budaya terus } \\
\text { mengembangkan } \\
\text { kualitas seni dan } \\
\text { budaya }\end{array}$ & $\begin{array}{l}\text { - Adanya upaya } \\
\text { innovasi dari pelaku } \\
\text { seni, budayawan dan } \\
\text { desainer busana } \\
\text { terhadap busana } \\
\text { daerah khususnya } \\
\text { busana daerah Sunda. } \\
\text { - Munculnya kesadaran } \\
\text { dari generasi muda } \\
\text { untuk mencari } \\
\text { kembali identitas etnis } \\
\text { khususnya etnis } \\
\text { Sunda, salah satunya } \\
\text { melalui pemakaian } \\
\text { iket Sunda dalam } \\
\text { kesempatan berbusana }\end{array}$ \\
\hline
\end{tabular}




\begin{tabular}{|c|c|c|c|}
\hline No. & Waktu & Kondisi & Keberadaan Iket Sunda \\
\hline & & $\begin{array}{ll}\text { e. } & \text { Media informasi } \\
\text { seperti televisi dan } \\
\text { media cetak } \\
\text { berkembang pesat } \\
\text { sebagai sarana yang } \\
\text { dapat memberikan } \\
\text { kesempatan dan } \\
\text { peluang kepada para } \\
\text { pelaku seni } \\
\text { f. } \\
\text { Berkembangnya } \\
\text { pengaruh film import }\end{array}$ & sehari-hari \\
\hline
\end{tabular}

Tabel 5 Pemetaan pemakaian iket Sunda berdasarkan karakteristik bentuk fisik, fungsi pemakaian, warna, ragam hias, bahan, ukuran, cara pakai dan kesempatan pemakaian

\begin{tabular}{|c|c|c|c|}
\hline & $\begin{array}{l}\text { Faktor } \\
\text { perubahan }\end{array}$ & $\begin{array}{c}\text { Bihari } \\
\text { (masa dahulu) }\end{array}$ & $\begin{array}{c}\text { Kiwari } \\
\text { (masa sekarang) }\end{array}$ \\
\hline 1. & Bentuk fisik & $\begin{array}{ll}\text { a. } & \text { Barangbang Semplak } \\
b . & \text { Parékos : Parékos Nangka, } \\
& \text { Parékos Jéngkol, Tutup } \\
& \text { Liwet, Lohén } \\
\text { c. } & \text { Porténg } \\
\text { d. } & \text { Kolé Nyangsang }\end{array}$ & $\begin{array}{l}\text { a. Tidak terbatas pada model } \\
\text { tradisional } \\
\text { b. Mengikuti trend hiasan } \\
\text { penutup kepala }\end{array}$ \\
\hline 2. & $\begin{array}{l}\text { Fungsi } \\
\text { pemakaian }\end{array}$ & $\begin{array}{l}\text { a. Formal } \\
\text { b. Informal }\end{array}$ & $\begin{array}{l}\text { a. Secara umum sebagai penanda } \\
\text { etnis Sunda dari kalangan } \\
\text { somah } \\
\text { b. Penanda etnis Sunda pada } \\
\text { busana adat dan tari } \\
\text { pertunjukan rakyat }\end{array}$ \\
\hline 3. & Warna & Warna tradisional Sunda & Warna tidak terbatas \\
\hline 4. & Ragam hias & $\begin{array}{l}\text { Ragam hias dengan pola yang } \\
\text { sudah baku }\end{array}$ & $\begin{array}{l}\text { berbagai motif dengan hiasan } \\
\text { bros, payet, mute, manik }\end{array}$ \\
\hline 5. & Bahan & Kain mori & $\begin{array}{l}\text { Kain mori dan berbagai jenis } \\
\text { kain }\end{array}$ \\
\hline 6. & Ukuran & $\begin{array}{l}\text { Ukuran saiket atau satotopong } \\
(90 \times 90 \mathrm{~cm} \text { atau } 100 \times 100 \mathrm{atau} \\
105 \times 105 \mathrm{~cm})\end{array}$ & Ukuran separon \\
\hline
\end{tabular}




\begin{tabular}{|c|c|c|c|}
\hline & $\begin{array}{c}\text { Faktor } \\
\text { perubahan }\end{array}$ & $\begin{array}{c}\text { Bihari } \\
\text { (masa dahulu) } \\
\end{array}$ & $\begin{array}{c}\text { Kiwari } \\
\text { (masa sekarang) }\end{array}$ \\
\hline 7. & Cara pakai & $\begin{array}{l}\text { Dipakai dengan cara diikatkan } \\
\text { langsung pada saat berdandan } \\
\text { dengan cara tertentu untuk } \\
\text { menghasilkan model yang baku }\end{array}$ & $\begin{array}{l}\text { a. Dibuat model siap pakai } \\
\text { b. Dibuat menjadi model yang } \\
\text { lebih sederhana } \\
\text { c. Meniru berbagai model iket } \\
\text { dari wilayah lain di Indonesia } \\
\text { dan berbagai wilayah lain di } \\
\text { dunia }\end{array}$ \\
\hline 8. & $\begin{array}{l}\text { Kesempatan } \\
\text { pemakaian }\end{array}$ & $\begin{array}{l}\text { a. Sehari-hari } \\
\text { b. Upacara adat }\end{array}$ & $\begin{array}{l}\text { a. Sehari-hari } \\
\text { b. Upacara adat } \\
\text { c. Pelengkap busana tari } \\
\text { pertunjukan rakyat }\end{array}$ \\
\hline
\end{tabular}

\section{$4 \quad$ Kesimpulan}

a. Iket Sunda dewasa ini semakin jarang digunakan.

Penyebab ditinggalkannya busana daerah khususnya iket Sunda adalah karena masyarakat Sunda khususnya mengalami pergeseran tata nilai setelah Indonesia merdeka. Masyarakat Sunda lahir dalam sikap baru yang berhubungan dengan cara pandang, cara berfikir dan tindakan. Salah satu pemikiran baru itu adalah busana tradisional dianggap tidak praktis dan tidak sesuai dengan perkembangan zaman, serta tidak adanya peraturan pemerintah secara khusus mengenai cara berbusana yang didasarkan stratifikasi masyarakat.

Iket Sunda memiliki ciri khas yang membedakan dengan tutup kepala yang lain, yaitu: bentuknya sederhana,terbuat dari kain persegi empat yang dibentuk menjadi segi tiga,pada bagian tengah atas kepala tertutup,memiliki nama yang diambil dari alam lingkungan sekitar.

b. Adanya perubahan fungsi iket Sunda

Sekarang ini, iket Sunda digunakan masyarakat khususnya pria sebagai :pelindung kepala., model yang beragam digunakan sebagai hiasan pada bagian kepala yang dapat menunjang penampilan. Keberadannya kini tidak lagi sebagai pembeda identitas atau status dalam masyarakat, sehingga pemakaiannyapun dipadankan dengan berbagai busana pria yang sifatnya moderen. 
c. Adanya perubahan nilai yang menyebabkan perubahan fungsi pemakaian iket Sunda disebabkan:

1) Peraturan khusus seperti adanya ketentuan berbusana di sekolah, di kantor yang mengharuskan mengenakan seragam dengan ketentuan khusus, lambat laun secara tidak langsung mematikan tradisi yang ada.

2) Masyarakat dewasa ini cenderung mengikuti trend mode busana modern.

3) Meningkatnya teknologi pertekstilan menyebabkan banyaknya pilihan bahan tekstil.

4) Kepraktisan dalam berbusana.

5) Berkembangnya model rambut pria modern.

6) Adanya persepsi masyarakat yang salah terhadap pemakai iket Sunda dan terhadap iket Sunda-nya sendiri. Orang yang memakai iket Sunda dipersepsikan sebagai dukun, pendekar, atau orang yang berhubungan erat dengan hal-hal mistik.

\section{Referensi}

[1] Ardiwinata, D.K. 1916. Tatakrama Oerang Soenda Jilid I, Kaoem Moeda, Bandung, p. 5.

[2] Arifah. 2003. Teori Desain Busana, Yapemdo, Bandung, p. 81.

[3] Oxford Advanced Learner's Dictionary 2000, p. 704.

[4] Kamus Umum Basa Sunda, p. 61,1980.

[5] Hidayat Suryalaga, salah satu tokoh Sunda dalam wawancara tanggal 20 Juli 2006.

[6] Nandang Sunaryo merupakan keturunan ke-6 dari Eyang Agung Zaenal Arif (pendiri kampung Mahmud yang berada di kodya Bandung) dalam wawancara tanggal 14 April 2006.

[7] Adil Fadilah Kusumah adalah ketua Yayasan Atikan Sunda dalam wawancara tanggal 3 April 2006.

[8] Sukatma adalah ketua pelaksana upacara adat ngalaksa di desa Rancakalong Sumedang yang dilaksanakan dari tanggal 6-12 Juli dan juga sebagai ketua rombongan petani Rancakalong, dalam wawancara tanggal 8 Juli 2006.

[9] H. Ecep Hidayat, merupakan keturunan ke-5 dari Eyang Agung Zaenal Arif (pendiri kampung Mahmud yang berada di kodya Bandung) dalam wawancara tanggal 15 April 2006.

[10] Djoemena, Nian S., Ungkapan Sehelai Batik : Its Mystery and Meaning, Penerbit Djambatan, Jakarta, p. 1, 199) . 
[11] Darmaprawira, W.A., Sulasmi. 2002. Warna:Teori dan Kreativitas Penggunaannya, Edisi ke-2, Penerbit ITB, pp. 162-163. 